MAREK ZIELIŃSKI*

\title{
KLASYFIKACJE AgENCJI ZDECENTRALIZOWANYCH UNII EUROPEJSKIEJ
}

\section{Wstęp}

Agencje zdecentralizowane (inaczej regulacyjne) Unii Europejskiej stały się obecnie trwałym elementem struktury instytucjonalnej tej organizacji ${ }^{1}$. Agencje te ustanawiane były stopniowo począwszy od lat 70-tych XX w., a proces ich rozwoju uległ w ostatnich latach znacznemu przyspieszeniu. Zauważyć jednak wypada, że jak dotąd nie opracowano jednej powszechnie obowiązującej definicji agencji zdecentralizowanych, a podobny brak widoczny jest także w odniesieniu do ich klasyfikacji. Liczne próby dokonania klasyfikacji agencji UE podejmowane są w związku z tym w piśmiennictwie², a także przez samą Komisję Europejską (Komisja), której działania w tej mierze spotkały się jednak z uzasadnioną krytyką ze strony przedstawicieli doktryny ${ }^{3}$, jak i Parlamentu Europejskiego ${ }^{4}$.

*Dr hab., Uniwersytet Śląski; e-mail: marek.zielinski@us.edu.pl.

${ }^{1} \mathrm{~W}$ związku z gwałtownym wzrostem liczby agencji oraz poszerzaniem się zakresu kompetencji agencji UE, w piśmiennictwie wspomina się o procesie tzw. agencyzacji (agencification); zob. np. M. Chamon, Agencification in the United States and Germany and what the EU might learn from it, "German Law Journal" 2016, nr 1, s. 120 i n.; H.C.H. Hofmann, A. Morini, Constitutional aspects of the pluralisation of the EU executive through "agencification", „European Law Review” 2012, nr 4, s. 419 i n.

2 E. Vos, EU Agencies: Features, Framework and Future, „Maastricht Faculty of Law Working Paper" 2013, nr 3, s. 9-15; P. Craig, EU Administrative Law, Oxford 2012, s. 148-154.

${ }^{3}$ E. Chiti, An Important Part of the EU's Institutional Machinery: Features, Problems and Perspectives of European Agencies, „Common Market Law Review” 2009, nr 5, s. 1398.

${ }^{4}$ Rezolucja Parlamentu Europejskiego z 23 kwietnia 2009 r. w sprawie zarządzania finansami i kontroli agencji UE (Dz. Urz. UE z 26 września 2009 r., L 255/206), pkt 6. 
Celem prezentowanego opracowania jest $\mathrm{w}$ związku z powyższym przedstawienie klasyfikacji agencji UE, co dokonane zostanie w oparciu o podejścia: temporalne, instrumentalne, strukturalne oraz funkcjonalne. Pamiętać jednak należy, że wobec braku jednolitej definicji agencji zdecentralizowanych, wszelkie próby ich klasyfikacji mogą być obarczone pewnymi błędami. Z tego też powodu klasyfikacje te należy traktować ostrożnie, mając na względzie to, że stanowią one jedynie próby wprowadzenia większej jasności co do rodzajów agencji zdecentralizowanych i funkcji przez nie wykonywanych ${ }^{5}$. Wszelkie klasyfikacje (w tym przedstawione $\mathrm{w}$ prezentowanym opracowaniu), mają bowiem na celu jedynie lepsze zrozumienie i uporządkowanie pewnej rzeczywistości, która $\mathrm{w}$ innym przypadku pozostawałaby niejasna, nieprzejrzysta i tym samym mniej komunikatywna w odbiorze ${ }^{6}$. Rozważania poświęcone klasyfikacji agencji zdecentralizowanych UE są jednak z oczywistych względów poprzedzone przedstawieniem ich definicji.

\section{Pojęcie agencji zdecentralizowanej Unii Europejskiej}

Pomimo ich wzrastającej liczby oraz zakresu kompetencji przekazywanych im do realizacji, jak dotąd brak jest jednej, powszechnie przyjętej, urzędowej definicji agencji zdecentralizowanych $\mathrm{UE}^{7}$. W związku z tym w doktrynie zwraca się uwagę na kilka elementów, które sprawiają że dana jednostka organizacyjna UE może zostać uznana za jej agencję zdecentralizowaną. W pierwszej kolejności zwrócić trzeba uwagę na to, że agencje są organami o charakterze stałym. Cecha ta odróżnia agencje zdecentralizowane od tzw. agencji wykonawczych, które tworzone są przez

${ }^{5}$ H.C.H. Hofmann, G.C. Rowe, A.H. Türk, Administrative Law and Policy of the European Union, Oxford 2011, s. 293.

${ }^{6}$ W. Kubik, Klasyfikacje prawne, Toruń 1981, s. 66.

${ }^{7}$ M. Chamon, EU Agencies. Legal and Political Limits to the Transformation of the EU Administration, Oxford 2016, s. 5; M. Zieliński, Agencje Unii Europejskiej, [w:] R. Grzeszczak, A. Szczerba-Zawada (red.), Prawo administracyjne Unii Europejskiej, Warszawa 2016, s. 164. Zob. także Analytical Fiche Nr 1, Definition and classification of „European Regulatory Agency", Detailed analytical papers 2010, www. https://europa.eu/european-union/sites/europaeu/files/docs/body/fiche_1_sent_to_ep_cons_2010-12-15_en.pdf [dostęp: 21.03.2017 r.]. 
Komisję na czas określony ${ }^{8}$. Od zasady tej mogą zdarzać się pewne wyjątki, jak np. Europejska Agencja ds. Bezpieczeństwa Sieci i Informacji (ENISA), którą pierwotnie utworzono na okres 9 lat i 6 miesięcy ${ }^{9}$ (później sukcesywnie przedłużany). Zarówno jednak Komisja ${ }^{10}$, jak i przedstawiciele doktryny, uznają ENISA za agencję zdecentralizowana, akceptując, że stanowi ona pewien wyjątek od reguły ${ }^{11}$. Po drugie, agencje zdecentralizowane, inaczej niż organizacje międzynarodowe tworzone przez UE ${ }^{12}$ albo podmioty prawa prywatnego państw członkowskich biorące udział w wykonywaniu celów $\mathrm{UE}^{13}$, są organami prawa publicznego UE. W sprawie Alaimo Trybunał Sprawiedliwości UE (TSUE) uznał w szczególności, że Europejskie Centrum Rozwoju Kształcenia Zawodowego (Cedefop) jest „częścią Wspólnot Europejskich” i, co się z tym wiąże, posiada charakter „organu wspólnotowego" ${ }^{14}$. Po trzecie, agencje ustanawiane są na podstawie aktów prawa pochodnego UE, czego nie zmienia fakt, że niektóre z nich (jak np. Europejska Agencja Obrony - EDA) wspomniane są w przepisach prawa pierwotnego UE. Po czwarte, cechą agencji jest posiadanie przez nie odrębnej od UE osobowości prawnej, co pozwala odróżnić je od szeregu innych organów UE i nadaje im cechę (relatywnej) niezależności ${ }^{15}$. Dobrym przykładem organu UE nieposiadającym osobowości prawnej (i w związku z tym niebędącym agencją UE) jest Europejska Służba Działań Zewnętrznych (ESDZ), która na podstawie aktu ją ustanawiające-

${ }^{8}$ Na temat tego typu agencji zob. M. Zieliński, Agencje wykonawcze UE, „Europejski Przegląd Sądowy" 2014, nr 6, s. 15 i n.

9 Rozporządzenie (WE) nr 460/2004 Parlamentu Europejskiego i Rady z dnia 10 marca 2004 r. (Dz. Urz. UE z 13 marca 2004, L 77/1), art. 27.

${ }^{10}$ Komunikat Komisji do Parlamentu Europejskiego i Rady, Przyszłość agencji Europejskich, Bruksela, dn. 11.3.2008, KOM(2008) 135 wersja ostateczna, s. 8.

${ }_{11}$ M. Chamon, EU Agencies, s. 10.

12 Jak było to z Europejskim Urzędem Policji przed 2009 r.; zob. A. De Moor, G. Vermeulen, The Europol Council Decision: Transforming Europol into an Agency of the European Union, "Common Market Law Review” 2010, nr 4, s. 1092.

${ }_{13}$ Jak jest to obecnie np. z Europejskim Instrumentem Stabilności Finansowej, który jest spółką utworzoną na podstawie prawa wewnętrznego Luxemburga, zob. EFSF Framework Agreement, http://www.efsf.europa.eu/attachments/20111019_efsf_framework_ agreement_en.pdf [dostęp: 21.03.2017 r.].

${ }^{14}$ Wyrok TS z 13 maja 1982 r. w sprawie C 16/81 - Agata Alaimo v. Komisja Wspólnot Europejskich, ECLI:EU:C:1982:154, pkt 9 i 11.

${ }^{15}$ Na temat podmiotowości w prawie UE zob. M. Ruffert, Personality under EU Law: A Conceptual Answer towards the Pluralisation of the EU, „European Law Journal” 2014, nr 3, s. 346 i $n$. 
go ma tylko zdolność prawną (legal capacity), niezbędną do wykonywania przypisanych jej zadań i realizacji wyznaczonych jej celów ${ }^{16}$.

W oparciu o przedstawione powyżej cechy agencje zdecentralizowane UE można zdefiniować jako: stałe organy działające w oparciu o prawo UE, utworzone na podstawie aktów prawa pochodnego tej organizacji i wyposażone w odrębną od UE osobowość prawną ${ }^{17}$.

\section{Klasyfikacja agencji ze względu na czas ich powstania (podejście temporalne)}

W piśmiennictwie wskazuje się, że agencje UE powstawały w czterech „falach" lub też że występują cztery różne "generacje” tych agencji ${ }^{18}$.

Pierwsza fala powstawania agencji datowana jest na lata 70-te XX w., gdyż rozpoczęła się wraz z ustanowieniem Europejskiego Funduszu Współpracy Monetarnej ${ }^{19}$, Cedefop ${ }^{20}$ oraz Europejskiej Fundacji na rzecz Poprawy Warunków Życia i Pracy ${ }^{21}$ (Eurofound). Te początkowe działania w kierunku agencyzacji nie stanowiły jednak znaczącego przełomu instytucjonalnego, ponieważ doprowadziły do utworzenia tylko trzech agencji, które posiadały bardzo ograniczone kompetencje w specyficznych dziedzinach, a także dlatego, że nie trwały one długo, ponieważ w ciągu następnych 15 lat nie doszło do powstania kolejnych agencji ${ }^{22}$.

${ }^{16}$ Decyzja Rady z 7 lipca 2010 r. określająca organizację i zasady funkcjonowania Europejskiej Służby Działań Zewnętrznych (Dz. Urz. UE z 3 sierpnia 2010 r., L 201/30), art. 1 ust. 2.

17 M. Chamon, EU Agencies, s. 15.

18 Tamże, s. 19; zob. także D. Geradin, N. Petit, The Development of Agencies at EU and National Levels: Conceptual Analysis and Proposals for Reform, "Jean Monnet Working Paper" 01/04, s. 37.

${ }^{19}$ Regulation (EEC) of the Council of 3 April 1973 establishing a European Monetary Cooperation Fund (Dz. Urz. WE z 5 kwietnia 1973 r., L 89/2). Fundusz ten został następnie rozwiązany w związku z ustanowieniem Europejskiego Instytutu Monetarnego.

${ }^{20}$ Rozporządzenie Rady nr 337/75 z dnia 10 lutego 1975 r. ustanawiające Europejskie Centrum Rozwoju Kształcenia Zawodowego (Dz. Urz. WE z 13 lutego 1975 r., L 39/1; polska wersja specj. 05/t. 1, s. 175).

${ }^{21}$ Rozporządzenie Rady nr 1365/75 z dnia 26 maja 1975 r. w sprawie utworzenia Europejskiej Fundacji na Rzecz Poprawy Warunków Życia i Pracy (Dz. Urz. WE z 30 maja 1975 r., L 139/1).

${ }^{22}$ D. Geradin, N. Petit, The Development, s. 37. 
Druga generacja agencji UE zaczęła być stopniowo tworzona z początkiem lat 90-tych XX w. wraz z utworzeniem Europejskiej Agencji Środowiska ${ }^{23}$ (EEA) oraz Europejskiej Fundacji Kształcenia ${ }^{24}$ (ETF). W dalszej kolejności utworzone zostały: Europejskie Centrum Monitorowania Narkotyków i Narkomaniii ${ }^{25}$ (EMCDDA), Europejska Agencja ds. Leków $^{26}$ (EMA), Urząd Unii Europejskiej ds. Własności Intelektualnejej (EUIPO), Europejska Agencja ds. Bezpieczeństwa i Ochrony Zdrowia

${ }^{23}$ Rozporządzenie Rady nr 1210/90 z dnia 7 maja 1990 r. w sprawie ustanowienia Europejskiej Agencji Ochrony Środowiska oraz europejskiej sieci informacji i obserwacji środowiska (Dz. Urz. WE z 11 maja 1990 r., L 120/1; polska wersja specj. 15/t. 1, s. 396). Obecnie jest to rozporządzenie Parlamentu Europejskiego i Rady nr 401/2009 z dnia 23 kwietnia 2009 r. w sprawie Europejskiej Agencji Środowiska oraz Europejskiej Sieci Informacji i Obserwacji Środowiska (Dz. Urz. UE z 21 maja 2009 r., L 126/13).

${ }^{24}$ Rozporządzenie Rady nr 1360/90 z dnia 7 maja 1990 r. ustanawiające Europejską Fundację Kształcenia (Dz. Urz. WE z 23 maja 1990 r., L 131/1; polska wersja specj. 01/t. 1, s. 203). Obecnie jest to rozporządzenie Parlamentu Europejskiego i Rady nr 1339/2008 z dnia 16 grudnia 2008 r. ustanawiające Europejską Fundację Kształcenia (Dz. Urz. UE z 31 grudnia 2008 r., L 354/82).

${ }^{25}$ Rozporządzenie Rady nr 302/93 z dnia 8 lutego 1993 r. w sprawie ustanowienia Europejskiego Centrum Monitorowania Narkotyków i Narkomanii (Dz. Urz. WE z 12 lutego 1993 r., L 36/1; polska wersja specj. 01/t. 1, s. 236). Obecnie jest to rozporządzenie Parlamentu Europejskiego i Rady nr 1920/2006 z dnia 12 grudnia 2006 r. w sprawie Europejskiego Centrum Monitorowania Narkotyków i Narkomanii (Dz. Urz. UE z 27 grudnia 2006 r., L 376/1).

${ }^{26}$ Pierwotnie agencja ta działała jako Europejska Agencja ds. Oceny Produktów Medycznych, zob. rozporządzenie Rady nr 2309/93 z dnia 22 lipca 1993 r. ustanawiające wspólnotowe procedury wydawania pozwoleń dla produktów leczniczych stosowanych u ludzi i do celów weterynaryjnych i nadzoru nad nimi oraz ustanawiające Europejską Agencję ds. Oceny Produktów Leczniczych (Dz. Urz. WE z 24 sierpnia 1993 r., L 214/1; polska wersja specj. 13/t. 12, s. 151). Obecna nazwa jest wynikiem zmian wprowadzonych przez rozporządzenie Parlamentu Europejskiego i Rady nr 726/2004 z dnia 31 marca 2004 r. ustanawiające wspólnotowe procedury wydawania pozwoleń dla produktów leczniczych stosowanych u ludzi i do celów weterynaryjnych i nadzoru nad nimi oraz ustanawiające Europejską Agencję Leków (Dz. Urz. UE z 30 kwietnia 2004 r., L 136/1).

${ }_{27}$ Pierwotnie agencja ta działała jako Urząd Harmonizacji Rynku Wewnętrznego, zob. rozporządzenie Rady nr 40/94 z dnia 22 grudnia 1993 r. w sprawie wspólnotowego znaku towarowego (Dz. Urz. WE z 14 stycznia 1994 r., L 11/1; polska wersja specj. 17/t. 1, s. 146). Obecna nazwa jest wynikiem zmian wprowadzonych przez rozporządzenie Parlamentu Europejskiego i Rady (UE) nr 2015/2424 z dnia 16 grudnia 2015 r. zmieniające rozporządzenie Rady (WE) nr 207/2009 w sprawie wspólnotowego znaku towarowego i rozporządzenie Komisji (WE) nr 2868/95 wykonujące rozporządzenie Rady (WE) nr 40/94 w sprawie wspólnotowego znaku towarowego oraz uchylające rozporządzenie Komisji (WE) nr 2869/95 w sprawie opłat na rzecz Urzędu Harmonizacji w ramach Rynku Wewnętrznego (znaki towarowe i wzory) (Dz. Urz. UE z 24 grudnia 2015 r., L 341/21). 
w Miejscu Pracy ${ }^{28}$ (EU-OSHA), Wspólnotowy Urząd Ochrony Odmian Roślin $^{29}$ (CPVO), Centrum Tłumaczeń dla organów UE ${ }^{30}$ (CdT), Europejska Agencja Praw Podstawowych ${ }^{31}$ (FRA), Europejska Agencja Odbudowy $^{32}$ (EAR). Ponadto $w$ omawianym okresie powołano agencje dawnego drugiego filara, jak Instytut UE Studiów nad Bezpieczeństwem ${ }^{33}$ (EUISS) oraz Centrum Satelitarne UE $^{34}$ (EUSC), a także agencje trzeciego filara, jak Agencja Unii Europejskiej ds. Współpracy Organów Ścigania ${ }^{35}$

${ }^{28}$ Rozporządzenie Rady nr 2062/94 z dnia 18 lipca 1994 r. ustanawiające Europejską Agencję ds. Bezpieczeństwa i Ochrony Zdrowia w Miejscu Pracy (Dz. Urz. WE z 20 sierpnia 1994 r., L 216/1; polska wersja specj. 05/t. 2, s. 205).

${ }^{29}$ Rozporządzenie Rady nr 2100/94 z dnia 27 lipca 1994 r. w sprawie wspólnotowego systemu ochrony odmian roślin (Dz. Urz. WE z 1 września 1994 r., L 227/1; polska wersja specj. 03/t. 16, s. 390).

${ }^{30}$ Rozporządzenie Rady nr 2965/94 z dnia 28 listopada 1994 r. ustanawiające Centrum Tłumaczeń dla organów Unii Europejskiej (Dz. Urz. WE 1994 L 314/1; polska wersja specj. 01/t. 1, s. 304).

${ }^{31}$ Pierwotnie agencja ta działała jako Europejskie Centrum Monitorowania Rasizmu i Ksenofobii, zob. rozporządzenie Rady nr 1035/97 z dnia 2 czerwca 1997 r. ustanawiające Europejskie Centrum Monitorowania Rasizmu i Ksenofobii (Dz. Urz. WE z 10 czerwca 1997 r., L 151/1; polska wersja specj. 01/t. 1, s. 416). Obecna nazwa jest wynikiem zmian wprowadzonych przez rozporządzenie Rady nr 168/2007 z dnia 15 lutego 2007 r. ustanawiające Agencję Praw Podstawowych Unii Europejskiej (Dz. Urz. UE z 22 lutego 2007 r., L 53/1).

32 Council regulation (EC) No. 2454/99 of 15 November 1999 (Dz. Urz. WE z 24 listopada 1999 r., L 299/1). Agencja ta zakończyła swoją działalność z dniem 31 grudnia 2006 r.

33 Wspólne działanie Rady nr 2001/554/WPZiB z dnia 20 lipca 2001 r. w sprawie ustanowienia Instytutu Unii Europejskiej Studiów nad Bezpieczeństwem (Dz. Urz WE z 25 lipca 2001 r., L 200/1; polska wersja specj. 18/t. 1, s. 183). Obecnie decyzja Rady nr 2014/75/ WPZiB z dnia 10 lutego 2014 r. w sprawie Instytutu Unii Europejskiej Studiów nad Bezpieczeństwem (Dz. Urz. UE z 12 lutego 2014 r., L 41/13).

${ }^{34}$ Wspólne działanie Rady nr 2001/555/WPZiB z dnia 20 lipca 2001 r. w sprawie ustanowienia Centrum Satelitarnego Unii Europejskiej (Dz. Urz. WE z 25 lipca 2001 r., L 200/5; polska wersja specj. 18/t. 1, s. 187). Obecnie decyzja Rady nr 2014/401/WPZiB z dnia 26 czerwca 2014 r. w sprawie Centrum Satelitarnego Unii Europejskiej i uchylenia wspólnego działania 2001/555/WPZiB w sprawie ustanowienia Centrum Satelitarnego Unii Europejskiej (Dz. Urz. UE z 27 czerwca 2014 r., L 188/73).

${ }^{35}$ Konwencja sporządzona na podstawie artykułu K.3 Traktatu o Unii Europejskiej w sprawie ustanowienia Europejskiego Urzędu Policji (Konwencja o Europolu), sporządzona w Brukseli dnia 26 lipca 1995 r. (Dz. U. z 2005 r. Nr 29, poz. 243). Obecnie rozporządzenie Parlamentu Europejskiego i Rady (UE) nr 2016/794 z dnia 11 maja 2016 r. w sprawie Agencji Unii Europejskiej ds. Współpracy Organów Ścigania (Europol), zastępujące i uchylające decyzje Rady 2009/371/WSiSW, 2009/934/WSiSW, 2009/935/WSiSW, 2009/936/ WSiSW i 2009/968/WSiSW (Dz. Urz. UE z 24 maja 2016 r., L 135/794). 
(Europol) oraz Agencja Unii Europejskiej ds. Szkolenia w Dziedzinie Ścigania $^{36}$ (Cepol).

W doktrynie wskazuje się, że druga generacja agencji zaznaczyła w wyraźniejszy sposób postępującą ewolucję administracji ówczesnych Wspólnot ${ }^{37}$. Wynika to po pierwsze $z$ większej liczby nowo powstałych agencji, a po drugie $\mathrm{z}$ tego, że swoim zakresem działalności zaczęły one obejmować zupełnie nowe dziedziny (ochrona środowiska, zagadnienia narkomanii itd.)

Powstanie agencji trzeciej generacji datowane jest na rok 2002, kiedy to utworzono Europejski Urząd ds. Bezpieczeństwa Żywności ${ }^{38}$ (EFSA). Podkreślić wypada, że agencje omawianej generacji zaczęły być tworzone z większym udziałem Komisji, jako część szerszej strategii wypracowanej w odpowiedzi na potrzeby związane z zapewnieniem zwiększonej odpowiedzialności oraz nowymi formami partnerstwa między różnymi szczeblami europejskiego zarządzania ${ }^{39}$. Wspomniana strategia postrzegała agencje jako organy odgrywające znaczącą rolę w szerszym kontekście realizacji zadań wykonawczych i definiowania zadań instytucji. W opinii Komisji nowo tworzone agencje powinny działać z większą niezależnością i w wyraźniej zdefiniowanych ramach określonych przez ustawodawstwo $\mathrm{UE}^{40}$. Na tworzenie agencji trzeciej generacji znaczący wpływ wywarły ponad to takie dokumenty Komisji, jak projekt porozumienia międzyinstytucjonalnego w sprawie utworzenia ram prawnych dla europejskich agencji regulacyjnych ${ }^{41}$, a także komunikat do Parlamentu Europejskiego i Rady w sprawie przyszłości agencji europejskich ${ }^{42}$. Agencje trzeciej generacji

${ }^{36}$ Decyzja Rady nr 2000/820/WSiSW z dnia 22 grudnia 2000 r. ustanawiająca Europejskie Kolegium Policyjne (Dz. Urz. WE z 30 grudnia 2000 r., L 336/1; polska wersja specj. 19/t. 4, s. 36). Obecnie rozporządzenie Parlamentu Europejskiego i Rady (UE) nr 2015/2219 z dnia 25 listopada 2015 r. w sprawie Agencji Unii Europejskiej ds. Szkolenia w Dziedzinie Ścigania (CEPOL) oraz zastępujące i uchylające decyzję Rady 2005/681/WSiSW (Dz. Urz. UE z 4 grudnia 2015 r., L 319/1).

37 D. Geradin, N. Petit, The Development, s. 37.

38 Rozporządzenie (WE) nr 178/2002 Parlamentu Europejskiego i Rady z dnia 28 stycznia 2002 r. ustanawiające ogólne zasady i wymagania prawa żywnościowego, powołujące Europejski Urząd ds. Bezpieczeństwa Żywności oraz ustanawiające procedury w zakresie bezpieczeństwa żywności (Dz. Urz. WE z 1 lutego 2002 r., L 31/1; polska wersja specj. 15/t. 6, s. 463).

${ }^{39}$ E. Vos, EU Agencies, s. 5.

${ }^{40}$ Commission: European Governance - a White Paper, COM(2001) 428 final.

${ }^{41} \operatorname{COM}(2005) 59$ końcowy, Bruksela dn. 25.02.2005.

${ }^{42} \mathrm{KOM}(2008) 135$ wersja ostateczna, Bruksela dn. 11.03.2008. 
obejmują ponadto: Europejską Agencję ds. Bezpieczeństwa Morskiego ${ }^{43}$ (EMSA), EuropejskąAgencję Bezpieczeństwa Lotnictwa ${ }^{44}$ (EASA), ENISA ${ }^{45}$, Europejskie Centrum ds. Zapobiegania i Kontroli Chorób ${ }^{46}$ (ECDC), Agencję Kolejową Unii Europejskiej" (ERA), Agencję Europejskiego GNSS ${ }^{48}$ (GSA), Europejską Agencję Straży Granicznej i Przybrzeżnej ${ }^{49}$ (Frontex),

${ }^{43}$ Rozporządzenie (WE) nr 1406/2002 Parlamentu Europejskiego i Rady z dnia 27 czerwca 2002 r. ustanawiające Europejską Agencję ds. bezpieczeństwa na morzu (Dz. Urz. WE z 5 sierpnia 2002 r., L 208/1; polska wersja specj. 07/t. 7, s. 3).

${ }^{44}$ Rozporządzenie (WE) nr 1592/2002 Parlamentu Europejskiego i Rady z dnia 15 lipca 2002 r. w sprawie wspólnych zasad w zakresie lotnictwa cywilnego i utworzenia Europejskiej Agencji Bezpieczeństwa Transportu Lotniczego (Dz. Urz. WE z 7 września 2002 r., L 240/1; polska wersja specj. 07/t. 7, s. 30).

${ }^{45}$ Rozporządzenie (WE) nr 460/2004 Parlamentu Europejskiego i Rady z dnia 10 marca 2004 r. ustanawiające Europejską Agencję ds. Bezpieczeństwa Sieci i Informacji (Dz. Urz. UE z 13 marca 2004 r. L 77/1). Obecnie rozporządzenie Parlamentu Europejskiego i Rady (UE) nr 526/2013 z dnia 21 maja 2013 r. w sprawie Agencji Unii Europejskiej ds. Bezpieczeństwa Sieci i Informacji (ENISA) oraz uchylające rozporządzenie (WE) nr 460/2004 (Dz. Urz. UE z 18 czerwca 2013 r., L 165/41).

${ }^{46}$ Rozporządzenie (WE) nr 851/2004 Parlamentu Europejskiego i Rady z dnia 21 kwietnia 2004 r. ustanawiające Europejskie Centrum ds. Zapobiegania i Kontroli Chorób (Dz. Urz. UE z 30 kwietnia 2004 r., L 142/1; polska wersja specj. 15/t. 8, s. 346).

${ }^{47}$ Pierwotnie agencja ta działała jako Europejska Agencja Kolejowa, zob. rozporządzenie (WE) Parlamentu Europejskiego i Rady nr 881/2004 z dnia 29 kwietnia 2004 r. ustanawiające Europejską Agencję Kolejową (Dz. Urz. UE z 30 kwietnia 2004 r., L 164/1; polska wersja specj. 07/t. 8, s. 214). Obecna nazwa jest wynikiem zmian wprowadzonych przez rozporządzenie Parlamentu Europejskiego i Rady (UE) nr 2016/796 z dnia 11 maja 2016 r. w sprawie Agencji Kolejowej Unii Europejskiej i uchylenia rozporządzenia (WE) nr 881/2004 (Dz. Urz. UE z 26 maja 2016 r., L 138/1) (dalej: rozporządzenie nr 2016/796).

${ }^{48}$ Pierwotnie agencja ta działała jako Europejski Organ Nadzoru GNSS, zob. rozporządzenie Rady (WE) nr 1321/2004 z dnia 12 lipca 2004 r. w sprawie ustanowienia struktur zarządzania europejskimi programami radionawigacyjnymi (Dz. Urz UE z 20 lipca 2004 r., L 246/1). Obecna nazwa jest wynikiem zmian wprowadzonych przez rozporządzenie Parlamentu Europejskiego i Rady (UE) nr 912/2010 z dnia 22 września 2010 r. ustanawiające Agencję Europejskiego GNSS, uchylające rozporządzenie Rady (WE) nr 1321/2004 w sprawie ustanowienia struktur zarządzania europejskimi programami radionawigacyjnymi i zmieniające rozporządzenie Parlamentu Europejskiego i Rady (WE) nr 683/2008 (Dz. Urz. UE z 20 października 2010 r., L 276/11).

${ }^{49}$ Pierwotnie agencja ta działała jako Europejska Agencja Zarządzania Współpracą Operacyjną na Zewnętrznych Granicach Państw Członkowskich UE, zob. rozporządzenie Rady (WE) nr 2007/2004 z dnia 26 października 2004 r. ustanawiające Europejską Agencję Zarządzania Współpracą Operacyjną na Zewnętrznych Granicach Państw Członkowskich Unii Europejskiej (Dz. Urz. UE z 25 listopada 2004 r., L 349/1). Obecnie rozporządzenie Parlamentu Europejskiego i Rady (UE) 2016/1624 z dnia 14 września 2016 r. w sprawie Europejskiej Straży Granicznej i Przybrzeżnej oraz zmieniające rozporządzenie Parlamentu Europejskiego i Rady (UE) 2016/399 i uchylające rozporządzenie (WE) nr 863/2007 Parlamen- 
Europejską Agencję Kontroli Rybołówstwa ${ }^{50}$ (EFCA), Europejską Agencję Chemikaliów $^{51}$ (ECHA), Europejski Instytut ds. Równości Kobiet i Mężczyzn $^{52}$ (EIGE), Agencję ds. Współpracy Organów Regulacji Energetyki ${ }^{53}$ (ACER), Organ Europejskich Regulatorów Łączności Elektronicznej ${ }^{54}$ (BEREC), Europejski Urząd Wsparcia w Dziedzinie Azylu ${ }^{55}$ (EASO). Ponadto $\mathrm{w}$ okresie tym powołano agencję $\mathrm{w}$ drugim filarze UE - tzn. EDA ${ }^{56}$ oraz w trzecim filarze UE - Europejską Jednostkę Współpracy Sądowej57 (Eurojust).

tu Europejskiego i Rady, rozporządzenie Rady (WE) nr 2007/2004 i decyzję Rady 2005/267/ WE (Dz. Urz. UE z 16 września 2016 r., L 251/1) (dalej: rozporządzenie nr 2016/1624).

${ }^{50}$ Rozporządzenie Rady (WE) nr 768/2005 z dnia 26 kwietnia 2005 r. ustanawiające Wspólnotową Agencję Kontroli Rybołówstwa oraz zmieniające rozporządzenie (WE) nr 2847/93 ustanawiające system kontroli mający zastosowanie do wspólnej polityki rybołówstwa (Dz. Urz UE z 21 maja 2005 r., L 128/1).

${ }^{51}$ Rozporządzenie (WE) nr 1907/2006 Parlamentu Europejskiego i Rady z dnia 18 grudnia 2006 r. w sprawie rejestracji, oceny, udzielania zezwoleń i stosowanych ograniczeń w zakresie chemikaliów (REACH) i utworzenia Europejskiej Agencji Chemikaliów, zmieniające dyrektywę 1999/45/WE oraz uchylające rozporządzenie Rady (EWG) nr 793/93 i rozporządzenie Komisji (WE) nr 1488/94, jak również dyrektywę Rady 76/769/EWG i dyrektywy Komisji 91/155/EWG, 93/67/EWG, 93/105/WE i 2000/21/WE (Dz. Urz. UE z 30 grudnia 2006 r., L 396/1).

${ }^{52}$ Rozporządzenie (WE) nr 1922/2006 Parlamentu Europejskiego i Rady z dnia 20 grudnia 2006 r. ustanawiające Europejski Instytut ds. Równości Kobiet i Mężczyzn (Dz. Urz. UE z 30 grudnia 2006 r., L 403/9).

${ }_{53}$ Rozporządzenie Parlamentu Europejskiego i Rady (WE) nr 713/2009 z dnia 13 lipca 2009 r. ustanawiające Agencję ds. Współpracy Organów Regulacji Energetyki (Dz. Urz. UE z 14 sierpnia 2009 r., L 211/1).

${ }^{54}$ Rozporządzenie Parlamentu Europejskiego i Rady (WE) nr 1211/2009 z dnia 25 listopada 2009 r. ustanawiające Organ Europejskich Regulatorów Łączności Elektronicznej (BEREC) oraz Urząd (Dz. Urz. UE z 18 grudnia 2009 r., L 337/1).

${ }_{55}$ Rozporządzenie Parlamentu Europejskiego i Rady (UE) nr 439/2010 z dnia 19 maja 2010 r. w sprawie utworzenia Europejskiego Urzędu Wsparcia w dziedzinie Azylu (Dz. Urz. UE z 29 maja 2010 r., L 132/11). Na temat działań podejmowanych w związku z powstawaniem tej agencji zob. F. Comte, A New Agency Is Born in the European Union: The European Asylum Support Office, "European Journal of Migration and Law" 2010, nr 12, s. 373 i n.

${ }^{56}$ Wspólne działanie Rady nr 2004/551/WPZiB z dnia 12 lipca 2004 r. w sprawie ustanowienia Europejskiej Agencji Obrony (Dz. Urz. UE z 17 lipca 2004 r., L 245/17). Obecnie decyzja Rady nr 2011/411/WPZiB z dnia 12 lipca 2011 r. określająca statut, siedzibę i zasady operacyjne Europejskiej Agencji Obrony oraz uchylająca wspólne działanie 2004/551/ WPZiB (Dz. Urz. UE z 13 lipca 2011 r., L 183/16).

${ }^{57}$ Decyzja Rady nr 2002/187/WSiSW z dnia 28 lutego 2002 r. ustanawiająca Eurojust w celu zintensyfikowania walki z poważną przestępczością (Dz. Urz. WE z 6 marca 2002 r., L 63/1; polska wersja specj. 19/t. 4, s. 197). 
Powstanie czwartej generacji agencji UE wiązane jest z koniecznością udzielenia właściwej odpowiedzi na niektóre skutki kryzysu finansowego ${ }^{58}$. W jego rezultacie ujawniły się bowiem pewne braki w zakresie współpracy, koordynacji i spójnego stosowania prawa UE w dziedzinie nadzoru finansowego, co wpłynęło na uchwalenie całego pakietu reform finansowych. Jako jeden z elementów tego pakietu ustanowiono również nową grupę agencji, które odróżniają się od istniejących wcześniej przede wszystkim szerszym zakresem kompetencji, które zostały im przyzna$\mathrm{ne}^{59}$. Do agencji tych można zaliczyć: Europejski Urząd Nadzoru Bankowego $^{60}$ (EBA), Europejski Urząd Nadzoru Ubezpieczeń i Pracowniczych Programów Emerytalnych ${ }^{61}$ (EIOPA), Europejski Urząd Nadzoru Giełd i Papierów Wartościowych ${ }^{62}$ (ESMA), które uzupełniła Jednolita Rada ds. Restrukturyzacji i Uporządkowanej Likwidacji ${ }^{63}$ (SRB). We wskazanym okresie utworzona została ponadto Europejska Agencja ds. Zarządzania Operacyjnego Wielkoskalowymi Systemami Informatycznymi w Przestrzeni Wolności Bezpieczeństwa i Sprawiedliwości ${ }^{64}$ (eu-LISA).

${ }^{58}$ E.M. Busuioc, European Agencies. Law and Practices of Accountability, Oxford 2013, s. 16.

59 I. H-Y Chiu, Power and Accountability in the EU Financial Regulatory Architecture: Examining Inter-Agency Relations, Agency Independence and Accountability, „European Journal of Legal Studies" 2015, nr 1, s. 67 i n.

${ }^{60}$ Rozporządzenie Parlamentu Europejskiego i Rady (UE) nr 1093/2010 z dnia 24 listopada 2010 r. w sprawie ustanowienia Europejskiego Urzędu Nadzoru (Europejskiego Urzędu Nadzoru Bankowego), zmiany decyzji nr 716/2009/WE oraz uchylenia decyzji Komisji 2009/78/WE (Dz. Urz. UE z 15 grudnia 2010 r., L 331/12).

${ }^{61}$ Rozporządzenie Parlamentu Europejskiego i Rady (UE) nr 1094/2010 z dnia 24 listopada 2010 r. w sprawie ustanowienia Europejskiego Urzędu Nadzoru (Europejskiego Urzędu Nadzoru Ubezpieczeń i Pracowniczych Programów Emerytalnych), zmiany decyzji nr 716/2009/WE i uchylenia decyzji Komisji 2009/79/WE (Dz. Urz. UE z 15 grudnia 2010 r., L 331/48) (dalej: rozporządzenie nr 1094/2010).

${ }^{62}$ Rozporządzenie Parlamentu Europejskiego i Rady (UE) nr 1095/2010 z dnia 24 listopada 2010 r. w sprawie ustanowienia Europejskiego Urzędu Nadzoru (Europejskiego Urzędu Nadzoru Giełd i Papierów Wartościowych), zmiany decyzji nr 716/2009/WE i uchylenia decyzji Komisji 2009/77/WE (Dz. Urz. UE z 15 grudnia 2010 r., L 331/84) (dalej: rozporządzenie nr 1095/2010).

${ }^{63}$ Rozporządzenie Parlamentu Europejskiego i Rady (UE) nr 806/2014 z dnia 15 lipca 2014 r. ustanawiające jednolite zasady i jednolitą procedurę restrukturyzacji i uporządkowanej likwidacji instytucji kredytowych i niektórych firm inwestycyjnych w ramach jednolitego mechanizmu restrukturyzacji i uporządkowanej likwidacji oraz jednolitego funduszu restrukturyzacji i uporządkowanej likwidacji oraz zmieniające rozporządzenie (UE) nr 1093/2010 (Dz. Urz. UE z 30 lipca 2014 r., L 225/1) (dalej: rozporządzenie nr 806/2014).

${ }^{64}$ Rozporządzenie Parlamentu Europejskiego i Rady (UE) nr 1077/2011 z dnia 25 października 2011 r. ustanawiające Europejską Agencję ds. Zarządzania Operacyjnego 


\section{Klasyfikacja agencji ze względu na charakter ich kompetencji (podejście instrumentalne)}

Klasyfikacja agencji dokonywana ze względu na charakter posiadanych przez nie kompetencji jest szczególnie przydatna dla dokonania oceny konstytucyjnych ograniczeń $\mathrm{w}$ delegowaniu tych kompetencji na agencje $^{65}$. Na tej podstawie podział przeprowadza się mając na względzie „intensywność prerogatyw powierzonych agencjom w celu wykonywania ich misji”66. Powyższe kryterium pozwala wyróżnić agencje: zwykłe (nieposiadające kompetencji decyzyjnych), pre-decyzyjne (które posiadają kompetencje decyzyjne de facto), rzeczywiste agencje decyzyjne, i jako ostatni typ - agencje stanowiące normy prawne ${ }^{67}$.

Pierwsza grupa - agencje zwykłe - obejmuje wszystkie te agencje zdecentralizowane, które wykonują zadania o charakterze pomocniczym, związanym z gromadzeniem informacji, organizowaniem sieci współpracy (np. Cedefop, Eurofound). W przypadku EEA zadania wyznaczone jej do realizacji obejmuja ponadto podejmowanie działań zachęcających do zwiększonej harmonizacji metod mierzenia środowiska oraz dostarczanie jednolitych metod oceny danych dotyczących środowiska ${ }^{68}$. Do kategorii tej zaliczamy agencje, które świadczą usługi na rzecz instytucji UE (jak np. $\mathrm{CdT}$ ) lub pełnią role obserwacyjne (jak EMCDDA). Wspólną cechą agencji tego typu jest to, że wykonując rozmaite zadania im przydzielone nie posiadają kompetencji decyzyjnych wobec podmiotów trzecich.

Druga grupa - agencje pre-decyzyjne - posiadają znaczący wpływ na kształt ostatecznych decyzji podejmowanych przez Komisję (EMEA, EFSA, EMSA, ERA) ${ }^{69}$. Agencje te, jakkolwiek nie mają formalnych kompetencji decyzyjnych, to posiadają jednak pewien zakres władzy w zakre-

Wielkoskalowymi Systemami Informatycznymi w Przestrzeni Wolności, Bezpieczeństwa i Sprawiedliwości (Dz. Urz. UE z 1 listopada 2011 r., L 286/1).

65 S. Griller, A. Orator, Everything under control? "The way forward" for European agencies in the footsteps of the Meroni doctrine, "European Law Review” 2010, nr 1, s. 12.

${ }^{66}$ D. Geradin, N. Petit, The Development, s. 48.

${ }^{67}$ S. Griller, A. Orator, Everything under control?, s. 13.

${ }^{68}$ G.V. Curtin, Regulation 1210/90: Establishment of the European Environmental Agency, „Boston College International and Comparative Law Review” 1991, nr 2, s. 325.

${ }^{69} \mathrm{Na}$ temat działania EFSA zob. A. Smith, S. Terry, D. Detken, 10 years of the European Food Safety Authority (EFSA) and the EU Food Safety System, "European Food and Feed Law Review" 2012, nr 3, s. 111 i n.; U. Uetzmann, Die Europäische Behörde für Lebensmittelsicherheit (EFSA), „Hansel Law Review” 2012, nr 1, s. 29 i n. 
sie przyjmowania niewiążących uchwał, które wywierają pewien wpływ i mają skutek podobny do wiążących decyzji podejmowanych przez Komisję. W przypadku ERA przykładem takich niewiążących uchwał są zalecenia dla Komisji przyjmowane na podstawie art. 4(a) rozporządzenia nr 2016/796 stanowiącego podstawę prawną działania tej agencji. W oparciu o powyższe zalecenia Komisja przygotowuje formalny projekt, który później przedkłada pod głosowanie państwom członkowskim ${ }^{70}$. Podobna sytuacja ma również miejsce w odniesieniu do EMSA, która wspomaga Komisję w pracach przygotowawczych na potrzeby uaktualnienia i tworzenia stosowanych aktów prawa UE, w szczególności zgodnie z rozwojem ustawodawstwa międzynarodowego ${ }^{71}$.

Dobrym przykładem są również opinie EMEA, która koordynuje ocenę i nadzór produktów medycznych ${ }^{72}$ lub opinie EFSA, która dokonuje naukowej oceny ryzyka związanego z niektórymi zagrożeniami ${ }^{73}$. W sprawie Artegodan Sąd orzekł, że „dla dokonania oceny zgodności z prawem decyzji Komisji (...), sądy wspólnotowe mogą być zmuszone do uprzedniego dokonania kontroli legalności opinii naukowej [EMEA] oraz tego, w jaki sposób Komisja wykonuje swoją władzę dyskrecjonalną" ${ }^{74}$. Mając na względzie to, że skarga w powyższej sprawie skierowana została przeciwko Komisji, która podjęła ostateczną decyzję, a nie EMEA, która przygotowała opinię, w piśmiennictwie omawiany typ agencji klasyfikowany jest poniżej agencji posiadających kompetencje decyzyjne ${ }^{75}$.

Trzecia grupa to agencje posiadające rzeczywiste kompetencje decyzyjne, czyli możliwość przyjmowania wiążących pod względem prawnym aktów adresowanych do podmiotów trzecich. Do agencji tego rodzaju zaliczyć można działające $\mathrm{w}$ dziedzinie ochrony własności intelektualnej EUIPO, CPVO, a także EASA działającą w dziedzinie bezpieczeństwa

${ }^{70}$ E. Versluis, E. Tarr, Improving Compliance with European Union Law via Agencies: The Case of European Railway Agency, "Journal of Common Market Studies" 2013, nr 2, s. 323.

${ }_{11}$ P. George-Dorel, European Maritime Safety Agency, "Constanta Maritime University Annals" 2013, t. 20, s. 271 i n.

${ }^{72}$ Zob. E. Chiti, European Agencies' Rulemaking: Powers, Procedures and Assessment, „European Law Journal" 2013, nr 1, s. 102-104.

${ }_{73}$ A. Smith, S. Terry, D. Detken, 10 years of the, s. 112-113.

74 Wyrok Sądu z 26 listopada 2002 r. w sprawach połączonych T-74/00, T-76/00, T-83/00 do T-85/00, T-132/00, T-137/00, T-141/00 - Artegodan GmbH v. Komisji, ECLI:EU:T:2002:283, pkt 199.

${ }^{75}$ S. Griller, A. Orator, Everything under control?, s. 14; inaczej D. Geradin, N. Petit, The Development, s. 48. 
lotnictwa, ECHA zajmującą się regulowaniem rynku chemikaliów ${ }^{76}$ oraz ACER np. w kwestiach technicznych dotyczących wprowadzenia jednolitego rynku energii ${ }^{77}$.

Utworzenie trzech agencji wchodzących w skład Europejskiego Urzędu Nadzoru (EUN), tzn. EBA, ESMA i EIOPA, stało się ważnym wydarzeniem związanym z rozwojem agencji UE posiadających kompetencje decyzyjne $^{78}$. Rozporządzenia stanowiące podstawę prawną funkcjonowania tych agencji umożliwiają im bowiem podejmowanie wiążących decyzji kierowanych bezpośrednio do władz krajowych lub instytucji finansowych. Przykładowo, zgodnie z art. 17 ust. 6 rozporządzenia nr 1094/2010, po spełnieniu pewnych warunków ${ }^{79}$, EIOPA może „(...) przyjąć decyzję indywidualną, skierowaną do instytucji finansowej, zobowiązującą ją do podjęcia działań niezbędnych do wypełnienia jej obowiązków wynikających z prawa Unii, w tym do zaprzestania określonych praktyk". Należy zwrócić uwagę na to, że charakter prawny powyższych decyzji jest dość trudny do określenia ${ }^{80}$. W piśmiennictwie wskazuje się, że decyzje podejmowane przez organy EUN zawierają normy indywidualne i konkretne, są aktami stosowania prawa i raczej nie można ich utożsamiać z decyzjami unijnymi, które podejmowane są na podstawie art. 288 TFUE ${ }^{81}$. Przykładem agencji posiadających kompetencje decyzyjne jest również SRB, która np. może przyjmować decyzje w sprawie działania w ramach restrukturyzacji i uporządkowanej likwidacji adresowane do instytucji finansowych, a także do krajowych organów ds. restrukturyzacji oraz uporządkowanej likwidacji ${ }^{82}$. Ponadto, w związku ze zmianami dokonanymi w zakresie

${ }^{76}$ M. Bronckers, Y. Van Gerven, Legal Remedies Under the EC's New Chemicals Legislation REACH: Testing a New Model of European Governance, "Common Market Law Review" 2009, nr 6, s. 1829.

77 D. Haverbeke, B. Naesens, W. Vandorpe, European Energy Markets and the New Agency for Cooperation of Energy Regulators, „Journal of Energy \& Natural Resources Law” 2010, nr 3, s. 419-420.

${ }^{78} \mathrm{P}$. Weismann, The European financial market supervisory authorities and their power to issue binding decisions, "Journal of International Banking Law and Regulation” 2012, nr 12, s. $495 \mathrm{i} \mathrm{n.}$

79 Tamże, s. 496.

${ }^{80}$ M. Fedorowicz, A. Michór, O charakterze prawnym decyzji nowych europejskich organów nadzoru nad rynkiem finansowym UE, „Europejski Przegląd Sądowy” 2011, nr 11, s. 24 i n.

81 Tamże, s. 25.

${ }^{82}$ Art. 16 ust. 1, art. 29 ust. 1 rozporządzenia nr 806/2014. Zob. także K. Alexander, European Banking Union: a legal and institutional analysis of the Single Supervisory Mechanism and the Single Resolution mechanism, "European Law Review” 2015, nr 2, s. 179-181. 
funkcjonowania ERA, agencji tej umożliwiono podejmowanie decyzji dotyczących: wydawania jednolitych certyfikatów bezpieczeństwa, zezwoleń na wprowadzenie pojazdów do obrotu, zezwoleń na wprowadzenie typu pojazdów do obrotu, dopuszczenia do eksploatacji przytorowych podsystemów "sterowanie" 83 .

Dodać należy, że indywidualne decyzje agencji należących do omawianej kategorii mogą być poddane kontroli przez ich komisje odwoławcze, które są niezależne od pozostałych organów tych agencji ${ }^{84}$.

Czwartą grupę stanowią agencje stanowiące normy prawne, które posiadają kompetencje porównywalne z krajowymi agencjami regulacyjnymi. Agencje te wyposażone są w kompetencje dyskrecjonalne, umożliwiające im przekładanie szeroko ujętych w ustawodawstwie wytycznych $\mathrm{w}$ konkretne instrumenty prawne. Ten rodzaj agencji zdecentralizowanych UE oparty jest na modelu amerykańskich agencji regulacyjnych posiadających szeroką władzę dyskrecjonalną ${ }^{85}$. W literaturze przedmiotu, która ukazała się przed 2011 r., dostrzegano możliwość istnienia tej grupy agencji, podkreślając jednak w owym czasie, że była to możliwość czysto teoretyczna ${ }^{86}$. Ustanowienie europejskich organów nadzoru nad rynkiem finansowym (EBA, ESMA, EIOPA), w 2011 r., zmieniło jednak ten stan rzeczy. Organy te są bowiem wyposażone w znaczące kompetencje quasi-prawotwórcze, umożliwiające im udział w stanowieniu prawa przez Komisję $e^{87}$. W odniesieniu do ESMA, zgodnie z art. 10 rozporządzenia nr 1095/2010, przyznano tej agencji prawo do przyjmowania projektów tzw. regulacyjnych standardów technicznych, które ESMA przedstawia Komisji do zatwierdzenia ${ }^{88}$. Kolejne kompetencje legislacyjne zostały przekazane ESMA na podstawie rozporządzenia nr 236/2012 w sprawie

83 Art. 4 pkt e rozporządzenia nr 2016/796.

${ }^{84}$ Szerzej zob. P. Chirulli, L. De Lucia, Specialised adjudication in EU administrative law the Boards of Appeal of EU agencies, "European Law Review” 2015, nr 6, s. 832 i n.

85 A. Forgács, The Regulatory Powers of Agencies in the United States and the European Union, "European Networks Law and Regulation Quarterly” 2015, nr 3, s. 11 i n.; D. Geradin, The Development of European Regulatory Agencies: What the EU Should Learn from American Experience, "Columbia Journal of European Law" 2004-2005, nr 1, s. 1 i n.

${ }^{86}$ S. Griller, A. Orator, Everything under control?, s. 14.

87 E.M. Busuioc, Rule-Making by the European Financial Supervisory Authorities: Walking a Tight Rope, „European Law Journal” 2013, nr 1, s. 112; N. Moloney, The European Securities and Markets Authority and institutional design for the EU financial market - a tale of two competences: Part 1: rule-making, "European Business Organization Law Review” 2011, nr 1, s. 41 i n.

88 Tamże, s. 64. 
krótkiej sprzedaży ${ }^{89}$. Zgodnie z art. 28 tego rozporządzenia ESMA przekazano uprawnienia interwencyjne (wykorzystywane w wyjątkowych okolicznościach) do wprowadzenia czasowego zakazu prowadzenia lub ograniczenia prowadzenia pewnych typów działalności finansowej, które zagrażają prawidłowemu funkcjonowaniu i integralności rynków finansowych lub stabilności całego systemu finansowego UE lub jego części ${ }^{90}$. Przekazanie ESMA tak daleko idących kompetencji interwencyjnych spotkało się ze sprzeciwem Zjednoczonego Królestwa, które wniosło do TS skargę o stwierdzenie nieważności art. 28 rozporządzenia nr 236/2012 ${ }^{91}$. W swoim wyroku TS UE nie podzielił jednak stanowiska skarżącego i nie unieważnił żądanego przepisu stwierdzając, że wykonywanie przez ESMA uprawnień wynikających z art. 28 rozporządzenia nr 236/2012 uzależnione jest od spełnienia licznych kryteriów i przesłanek, które określają zakres działania ESMA ${ }^{92}$. Ponadto uprawnienia te mogą podlegać kontroli sądowej dokonywanej przez TS UE w świetle celów określonych przez organ delegujący i tym samym zgodne są z wymogami ustanowionymi przez TS UE w wyroku w sprawie Meroni ${ }^{93}$. W ten sposób TS UE otworzył drogę do przekazywania agencjom zdecentralizowanym kolejnych uprawnień w zakresie stanowienia prawa.

${ }^{89}$ Rozporządzenie Parlamentu Europejskiego i Rady (UE) nr 236/2012 z dnia 14 marca 2012 r. w sprawie krótkiej sprzedaży i wybranych aspektów dotyczących swapów ryzyka kredytowego (Dz. Urz. UE z 24 marca 2012 r., L 86/1) (dalej: rozporządzenie nr 236/2012).

${ }_{90}$ Co do podstawy przekazania tego uprawnienia zob. art. 9 ust. 5 rozporządzenia nr 1095/2010.

91 Skarga wniesiona 1 czerwca 2012 r. sprawa C-270/12 - Zjednoczone Królestwo v. Parlamentowi Europejskiemu i Radzie Unii Europejskiej (Dz. Urz. UE z 8 września 2012 r., C 273/3).

${ }_{92}$ Wyrok TS z 22 stycznia 2014 r. w sprawie C-270/12 - Zjednoczone Królestwo v. Parlamentowi Europejskiemu i Radzie, ECLI:EU:C:2014:8, pkt 45; zob. także G. Lo Schiavo, A Judicial Re-Thinking on the Delegation of Powers to European Agencies Under EU Law? Comment on Case C-270/12 UK v. Council and Parliament, "German Law Journal” 2015, nr 2, s. 315 i n.; D. Adamski, The ESMA doctrine: a constitutional revolution and the economics of delegation, „European Law Review” 2014, nr 6, s. 812 i n.; V. Babis, The Power to Ban Short-Selling: The Beginning of a New Era for EU Agencies?, "Cambridge Legal Studies Research Papers” 2014, nr 27.

${ }^{93}$ Wyrok TS w sprawie C-270/12, pkt 53. Na temat wyroku w sprawie Meroni zob. D. Sobczyński, Agencje Unii Europejskiej, „Glosa” 2003, nr 6, s. 24-25. 


\section{Klasyfikacja agencji ze względu na podstawę prawną ich ustanowienia (podejście strukturalne)}

W piśmiennictwie dokonuje się również klasyfikacji agencji w oparciu o kryterium rodzaju traktatowej podstawy ich ustanowienia czy też inaczej - byłego filara UE, do którego podstawa ta należała ${ }^{94}$. Oczywistym jest, że z chwilą wejścia w życie Traktatu z Lizbony (TL) i zniesienia filarowej struktury UE omawiane podejście stało się znacznie mniej przydatne. Niemniej jednak przez długi czas po wejściu w życie TL oficjalna strona internetowa UE wciąż się nim posługiwała, a w swoim Wspólnym Podejściu z 2012 r. zainteresowane instytucje UE uznały, że nie dotyczy ono „agencji działających w dziedzinie polityki zagranicznej i bezpieczeństwa (... $)^{\prime 95}$.

Strukturalne podejście do klasyfikacji agencji zdecentralizowanych pozwala wyróżnić trzy ich kategorie, tzn. agencje wspólnotowe, agencje drugiego filara oraz agencje trzeciego filara. Zdecydowana większość agencji to dawne agencje wspólnotowe, które ustanowiono na podstawie art. 352 TFUE (dawny art. 308 TWE) ${ }^{96}$ lub art. 114 TFUE (dawny art. 95 TWE) dotyczącym zbliżania ustawodawstw w zakresie ustanawiania rynku wewnętrznego. $W$ odniesieniu do zastosowania tego ostatniego przepisu TS w sprawie C-217/04 dotyczącej utworzenia ENISA stwierdził, że brzmienie (obecnego) art. 114 TFUE „nie pozwala na wniosek, iż przepisy przyjęte przez prawodawcę wspólnotowego na podstawie tego artykułu powinny zostać ograniczone, jeśli chodzi o ich adresatów, wyłącznie do państw członkowskich. W rzeczywistości bowiem może okazać się konieczne, według oceny tego prawodawcy, przewidzenie możliwości ustanowienia organu wspólnotowego mającego za zadanie przyczynianie się do realizacji procesu harmonizacji (...)" $)^{\prime \prime 7}$. W ten sposób TS UE uznał, że w przypadku, gdy chodzi o skomplikowane i szybko zmieniające się okoliczności związane z rozwojem wiedzy technicznej, utworzenie agencji UE udzielającej porad w tym zakresie jest zgodne $\mathrm{z}$ art. 114 TFUE $^{98}$.

${ }^{94}$ M. Chamon, EU Agencies, s. 20.

95 Wspólne oświadczenie Parlamentu Europejskiego, Rady UE i Komisji Europejskiej w sprawie zdecentralizowanych agencji, 19.06.2012 r.

${ }^{96}$ H.C.H. Hofmann, G.C. Rowe, A.H. Türk, Administrative Law, s. 290.

97 Wyrok TS z 2 maja 2006 w sprawie C-217/04 - Zjednoczone Królestwo v. Parlamentowi Europejskiemu i Radzie Unii Europejskiej, ECLI:EU:C:2006:279, pkt 44.

${ }_{98}$ Zob. także H.C.H. Hofmann, Agencies in the European Regulatory Union, "TARN Working Paper" 2016, nr 5, s. 8. 
Poza ogólnymi przepisami Traktatów, przy tworzeniu agencji zdecentralizowanych instytucje UE opierały się (i opierają nadal) również na bardziej szczegółowych podstawach prawnych dotyczących transportu, ochrony środowiska naturalnego lub zdrowia ${ }^{99}$. Jako przykłady powoływania nowych agencji w oparciu o takie szczegółowe przepisy wskazać można EMSA, której dotyczy art. 100 ust. 2 TFUE $^{100}$ oraz EFCA, której dotyczy art. 43 ust. 2 TFUE ${ }^{101}$.

Należy jednak podkreślić, że tego typu praktyka wzbudza niekiedy wątpliwości co do tego, czy szczegółowe podstawy prawne zawarte $\mathrm{w}$ Traktatach nie są przez instytucje UE nadużywane. Przykładowo, w związku z uchwaleniem rozporządzenia nr 2016/1624 w sprawie utworzenia Europejskiej Straży Granicznej i Przybrzeżnej (co nastąpiło na podstawie art. 77 ust. 2 lit. b) i d) TFUE oraz art. 79 ust. 2 lit. c) TFUE) przekazano dodatkowe kompetencje policyjne na rzecz Frontex. W piśmiennictwie wskazuje się jednak, że przekazanie kompetencji policyjnych w zakresie zarządzania granicami wymaga bardziej szczegółowej podstawy prawnej niż wynikająca z dość ogólnego przepisu art. 77 ust. 2 lit. d) TFUE $^{102}$. W opinii autora prezentowanego opracowania podobne wattpliwości mogą zostać również wysunięte w odniesieniu do powiększenia zakresu kompetencji EMSA ${ }^{103}$ oraz EFCA ${ }^{104}$.

${ }_{99}$ Komisja podkreśliła bowiem, że skoro agencja zdecentralizowana jest instrumentem wprowadzania w życie konkretnej polityki wspólnotowej, podstawa prawna jej utworzenia powinna być oparta na przepisie Traktatu, który stanowi podstawę realizacji danej polityki, zob. Commission of the European Communities, The Operating Framework, s. 7.

${ }_{100}$ Przepis ten stanowi m.in., że Parlament i Rada stanowiąc zgodnie ze zwykłą procedurą ustawodawczą mogą ustanowić odpowiednie przepisy dotyczące transportu morskiego i lotniczego.

101 Przepis ten stanowi m.in., że Parlament i Rada stanowiąc zgodnie ze zwykłą procedurą ustawodawczą mogą ustanowić „inne przepisy niezbędne dla osiągnięcia celów wspólnej polityki rolnej i rybołówstwa".

102 Przepis ten stanowi, że dla realizacji celów w dziedzinie zarządzania granicami zewnętrznymi Parlament i Rada mogą przyjmować środki dotyczące „wszelkich środków niezbędnych dla stopniowego wprowadzania zintegrowanego systemu zarządzania granicami zewnętrznymi". Na ten temat zob. European Parliament, The proposal for a European Border and Coast Guard: evolution or revolution in external border management?, 2016 Study, PE 556.934, s. 26.

${ }^{103}$ Rozporządzenie Parlamentu Europejskiego i Rady (UE) 2016/1625 z dnia 14 września 2016 r. zmieniające rozporządzenie (WE) nr 1406/2002 ustanawiające Europejską Agencję Bezpieczeństwa Morskiego (Dz. Urz. UE z 16 września 2016 r., L 251/77).

104 Rozporządzenie Parlamentu Europejskiego i Rady (UE) 2016/1626 z dnia 14 września 2016 r. zmieniające rozporządzenie Rady (WE) nr 768/2005 ustanawiające Wspólnotową Agencję Kontroli Rybołówstwa (Dz. Urz. UE z 16 września 2016 r., L 251/80). 
Agencje dawnego drugiego filara UE pierwotnie zostały utworzone na podstawie wspólnych działań Rady, które obecnie zastąpiono decyzjami tej instytucji ${ }^{105}$. W doktrynie wskazuje się na pewne specyficzne cechy agencji dawnego drugiego filara UE (odnoszące się np. do ich szczególnej struktury wewnętrznej, zasad zatrudniania pracowników), które sprawiaja że czasami agencje te traktowane są odrębnie od pozostałych ${ }^{106}$.

Natomiast podstawy prawne utworzenia agencji dawnego trzeciego filara (Europol, Eurojust, Cepol) znaleziono w różnych przepisach TUE. W odniesieniu do Europol podstawą prawną stał się ówczesny art. K.3 TUE, który umożliwił zawarcie między państwami członkowskimi Konwencji $\mathrm{w}$ sprawie ustanowienia Europolu ${ }^{107}$. Pierwotnie więc Europol funkcjonował $\mathrm{w}$ oparciu o umowę międzynarodową i nie jako jedna $\mathrm{z}$ agencji, lecz raczej jako organizacja międzynarodowa. Obecnie podstawę prawną działania Europol stanowi art. 88 TFUE. W przypadku Cepol i Eurojust są to odpowiednio art. 87 ust. 2 b) TFUE oraz art. 85 ust. 1 TFUE.

\section{Klasyfikacja agencji ze względu na charakter zadań przez nie wykonywanych (podejście funkcjonalne)}

Mając na względzie rodzaj (charakter) zadań wykonywanych przez agencje zdecentralizowane UE, jako jedną z możliwych ich klasyfikacji można wskazać klasyfikację funkcjonalną. Podział ten pozwala wyróżnić po pierwsze agencje, które świadczą usługi na rzecz innych organów lub instytucji UE ${ }^{108}$. Do tej grupy agencji zaliczyć można CdT, ETF czy też eu-LISA. Drugą grupę stanowią tzw. agencje informacyjne, których podstawowym zadaniem jest przygotowywanie, gromadzenie i rozpowszechnianie informacji. Trzecia grupa to agencje udzielające pomocy innym organom poprzez kształtowanie i dostarczanie im odpowiednich informacji stanowiących podstawę ich decyzji (np. EFCA, EMSA, Frontex). Ostatnia - czwarta grupa, to agencje rynku wewnętrznego, których działalność ściśle wiąże się z określaniem zasad i warunków funkcjono-

\footnotetext{
105 Zob. przyp. 33, 34, 56.

106 E. Vos, EU Agencies, s. 12.

107 Zob. przyp. 35.

108 Nieco odmiennie zob. D. Geradin, N. Petit, The Development, s. 43.
} 
wania rynku wewnętrznego ${ }^{109}$. Do tej grupy można zaliczyć CPVO, EUIPO, EBA, EIOPA, ESMA, SRB.

\section{Wnioski}

Klasyfikacje agencji zdecentralizowanych UE przeprowadzone w prezentowanym opracowaniu pozwalają na wyciągnięcie kilku wniosków.

Klasyfikacja agencji przeprowadzona w oparciu o kryterium temporalne nie jest szczególnie pożyteczna, ponieważ dość trudno zauważyć korelację pomiędzy czasem powstania danej agencji a jej charakterem. Jedynym widocznym trendem jest tylko to, że agencje tworzone bardziej współcześnie posiadają bardziej znaczące kompetencje. Zauważyć również można i to, że działalność agencji istniejących od dłuższego już czasu podlega w ostatnich latach istotnym reformom, które związane są z poszerzeniem zakresu ich kompetencji.

Pomimo tego, że struktura filarowa UE została zniesiona w grudniu 2009 r., skutki jej istnienia wciąż dostrzegalne są w kontekście funkcjonowania niektórych agencji UE. Wniosek ten jest szczególnie aktualny $\mathrm{w}$ odniesieniu do funkcjonowania agencji dawnego drugiego filara UE (EDA, EUISS, EUSC), których zasady działania charakteryzują się wieloma szczególnymi cechami.

Klasyfikacja agencji UE dokonana ze względu na charakter ich kompetencji dowodzi, że agencje te rzadko posiadają tylko jeden rodzaj kompetencji. Często zdarza się bowiem, że ta sama agencja ma np. kompetencje pre-decyzyjne (umożliwiające jej wpływ na ostateczny kształt decyzji podejmowanych przez Komisję) i jednocześnie sama może podejmować decyzje wiążące ich adresatów (ERA). Podobne uwagi można również wysunąć w odniesieniu do klasyfikacji funkcjonalnej agencji, ponieważ $\mathrm{z}$ reguły mogą one wykonywać różne rodzaje zadań.

Słowa kluczowe: Unia Europejska, agencje Unii Europejskiej 


\section{Bibliografia}

Adamski D., The ESMA doctrine: a constitutional revolution and the economics of delegation, „European Law Review” 2014, nr 6.

Alexander K., European Banking Union: a legal and institutional analysis of the Single Supervisory Mechanism and the Single Resolution mechanism, ",European Law Review" 2015, nr 2.

Babis V., The Power to Ban Short-Selling: The Beginning of a New Era for EU Agencies?, „Cambridge Legal Studies Research Papers” 2014, nr 27.

Bronckers M., Van Gerven Y., Legal Remedies Under the EC's New Chemicals Legislation REACH: Testing a New Model of European Governance, "Common Market Law Review" 2009, nr 6.

Busuioc E.M., European Agencies. Law and Practices of Accountability, Oxford 2013.

Busuioc E.M., Rule-Making by the European Financial Supervisory Authorities: Walking a Tight Rope, „European Law Journal” 2013, nr 1.

Chamon M., Agencification in the United States and Germany and what the EU might learn from it, "German Law Journal” 2016, nr 1.

Chamon M., EU Agencies. Legal and Political Limits to the Transformation of the EU Administration, Oxford 2016.

Chirulli P., De Lucia L., Specialised adjudication in EU administrative law the Boards of Appeal of EU agencies, „European Law Review” 2015, nr 6.

Chiti E., An Important Part of the EU's Institutional Machinery: Features, Problems and Perspectives of European Agencies, "Common Market Law Review" 2009, nr 5.

Chiti, E. European Agencies' Rulemaking: Powers, Procedures and Assessment, „European Law Journal” 2013, nr 1.

Comte F., A New Agency Is Born in the European Union: The European Asylum Support Office, "European Journal of Migration and Law” 2010, nr 12.

Craig P., EU Administrative Law, Oxford 2012.

Curtin G.V., Regulation 1210/90: Establishment of the European Environmental Agency, "Boston College International and Comparative Law Review” 1991, nr 2.

De Moor A., Vermeulen G., The Europol Council Decision: Transforming Europol into an Agency of the European Union, "Common Market Law Review" 2010, nr 4.

Fedorowicz M., Michór A., O charakterze prawnym decyzji nowych europejskich organów nadzoru nad rynkiem finansowym UE, "Europejski Przegląd Sądowy" 2011, nr 11.

Forgács A., The Regulatory Powers of Agencies in the United States and the European Union, „European Networks Law and Regulation Quarterly” 2015, nr 3.

George-Dorel P., European Maritime Safety Agency, „Constanta Maritime University Annals" 2013, t. 20. 
Geradin D., The Development of European Regulatory Agencies: What the EU Should Learn from American Experience, "Columbia Journal of European Law" 2004-2005, nr 1.

Geradin D., Petit N., The Development of Agencies at EU and National Levels: Conceptual Analysis and Proposals for Reform, "Jean Monnet Working Paper" 01/04.

Griller S., Orator A., Everything under control? The "way forward" for European agencies in the footsteps of the Meroni doctrine, "European Law Review” 2010, nr 1.

Haverbeke D., Naesens B., Vandorpe W., European Energy Markets and the New Agency for Cooperation of Energy Regulators, "Journal of Energy \& Natural Resources Law" 2010, nr 3.

Hofmann H.C.H., Agencies in the European Regulatory Union, "TARN Working Paper" 2016, nr 5.

Hofmann H.C.H., Morini A., Constitutional aspects of the pluralisation of the EU executive through "agencification”, "European Law Review” 2012, nr 4.

Hofmann H.C.H., Rowe G.C., Türk A.H., Administrative Law and Policy of the European Union, Oxford 2011.

H-Y Chiu I., Power and Accountability in the EU Financial Regulatory Architecture: Examining Inter-Agency Relations, Agency Independence and Accountability, „European Journal of Legal Studies” 2015, nr 1.

Kubik W., Klasyfikacje prawne, Torun 1981.

Lo Schiavo G., A Judicial Re-Thinking on the Delegation of Powers to European Agencies Under EU Law? Comment on Case C-270/12 UK v. Council and Parliament, "German Law Journal” 2015, nr 2.

Moloney N., The European Securities and Markets Authority and institutional design for the EU financial market - a tale of two competences: Part 1: rule-making, „European Business Organization Law Review” 2011, nr 1.

Ruffert M., Personality under EU Law: A Conceptual Answer towards the Pluralisation of the EU, „European Law Journal” 2014, nr 3.

Smith A., Terry S., Detken D., 10 years of the European Food Safety Authority (EFSA) and the EU Food Safety System, "European Food and Feed Law Review" 2012, nr 3.

Sobczyński D., Agencje Unii Europejskiej, „Glosa”, 2003, nr 6.

Uetzmann U., Die Europäische Behörde für Lebensmittelsicherheit (EFSA), „Hansel Law Review" 2012, nr 1.

Versluis E., Tarr E., Improving Compliance with European Union Law via Agencies: The Case of European Railway Agency, "Journal of Common Market Studies" 2013, nr 2.

Vos E., EU Agencies: Features, Framework and Future, „Maastricht Faculty of Law Working Paper" 2013, nr 3.

Weismann P., The European financial market supervisory authorities and their power to issue binding decisions, "Journal of International Banking Law and Regulation" 2012, nr 12. 
Zieliński M., Agencje Unii Europejskiej, [w:] R. Grzeszczak, A. Szczerba-Zawada (red.), Prawo administracyjne Unii Europejskiej, Warszawa 2016.

Zieliński M., Agencje wykonawcze UE, „Europejski Przegląd Sądowy” 2014, nr 6.

\section{CLASSIFICATIONS OF DECENTRALISED AGENCIES OF THE EUROPEAN UNION}

\section{S u m m a r y}

The article aims to present the classifications of decentralised agencies of the European Union. As a basis for classifications the Author used temporal, instrumental, structural as well as functional approach. The analysis in this paper clearly shows, that some of the classification of the EU agencies (eg. instrumental classification), show that the EU agencies very often defy attempts to classify them. For this reason, the Author notes, that despite their value for better understanding and bringing structure and insight into the functioning of EU agencies, all their classifications should be treated with some caution.

Key words: European Union, agencies of the European Union

\section{КЛАССИФИКАЦИИ ДЕЦЕНТРАЯИЗУЮЩИХ АГЕНТСТВ ЕВРОПЕЙСКОГО СОЮЗА}

P е 3 ro м e

Представленная статья имеет на цели осуществления классификации децентрализующих агентств Европейского союза. Как основания выполнения классификации приняты подходы: темпоральное, инструментальное, структурное и функциональное. Проведенный анализ позволяет констатировать, что ряд классификации агентства (напр. осуществленная, учитывая их характер компетенции) доказывает, что агентства очень часто выскальзывают их попыткам классификации. В связи с этим, Автор замечает, что кроме их значительной ценности для лучшего понимания, а также упорядоченности деятельности агентства и осуществляемых функций ними, всевозможное их классификации следует считать с большой осторожностью.

Ключевые слова: Европейский союз, агентства Европейского союза 